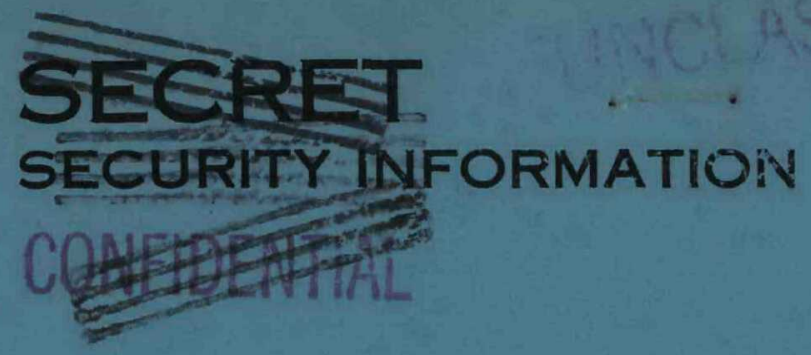

HW - 23141

CHEMISTRY - SEPARATION

PROCESSES FOR PLUTONIUM AND URANIUM

COPY NO. A

\title{
THE VALVE-ACTUATED PULSE COLUMN DESIGN AND OPERATION
}

\author{
AEC RESERTHH ANE DEVELOPIENT REPORT \\ BY

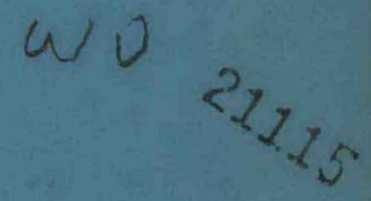

L. L. BURGER AND L. H. CLARK

TECHNICAL SECTION

ENGINEERING DEPARTMENT

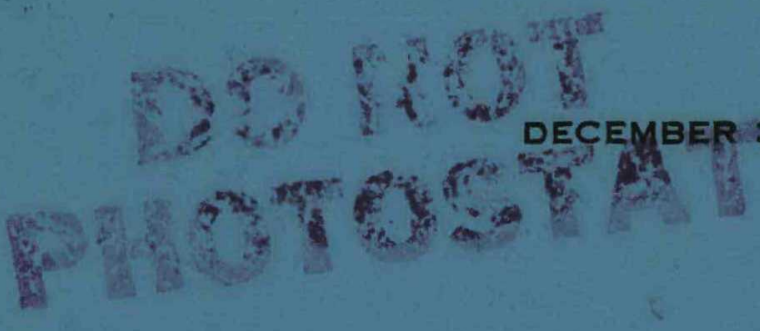

RESTRICIED DATA

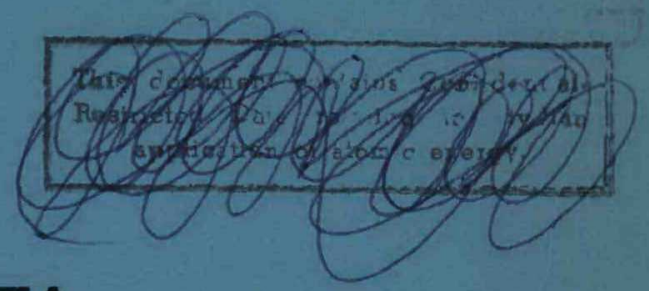

THIS DOCUMENT CONTANI KESTRICTED DATA AS DEFINED IN THE ATOMIC ENYSO ACFOF 1946. ITS TRANBMITTAL OR THE DISCLOSUR UNY UNAUTHORIZEO PERSON IS PROHIBITED.

\section{NUCLEONICS DIVISION}

RICHLAND, WASHINGTON

GENERAL G GLCETRIC

$\because \cdots \because: \therefore$ SECURITY INFORMATION

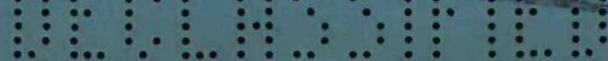




\section{DISCLAIMER}

This report was prepared as an account of work sponsored by an agency of the United States Government. Neither the United States Government nor any agency Thereof, nor any of their employees, makes any warranty, express or implied, or assumes any legal liability or responsibility for the accuracy, completeness, or usefulness of any information, apparatus, product, or process disclosed, or represents that its use would not infringe privately owned rights. Reference herein to any specific commercial product, process, or service by trade name, trademark, manufacturer, or otherwise does not necessarily constitute or imply its endorsement, recommendation, or favoring by the United States Government or any agency thereof. The views and opinions of authors expressed herein do not necessarily state or reflect those of the United States Government or any agency thereof. 


\section{DISCLAIMER}

Portions of this document may be illegible in electronic image products. Images are produced from the best available original document. 



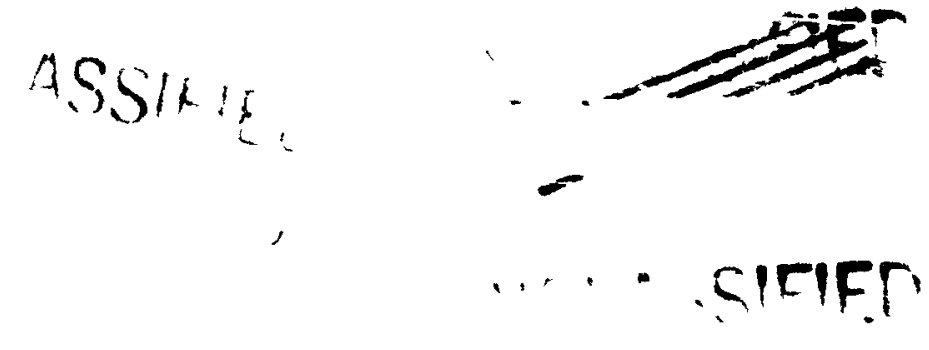

\section{IJNCLASSIFIED}

HW-23141

Chemistry-Separation

Processes For Plutonium

And Uranium

\section{AEC RESEARCH AND DEVELOPMENT REPORT}

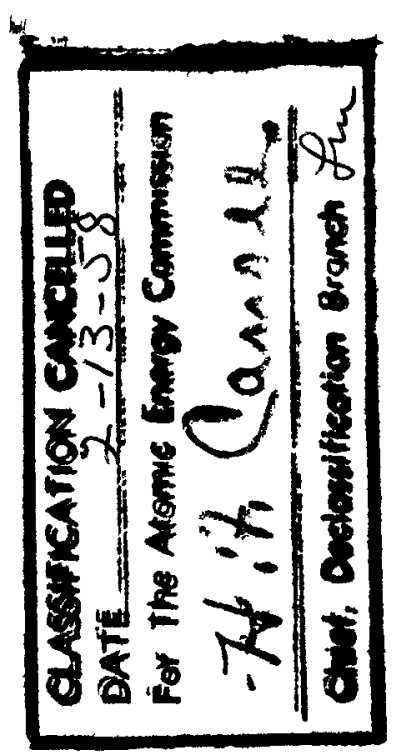

THE VALVE-ACTUATED PULSE COLUMN

DESIGN AND OPERATION

By

L. L. Burger and L. H. Clark

Chemical Research

Separations Technology Unit

December 3, 1951

NUCLEONICS DIVISION

RICHLAND, WASHINGTON

Operated for the Atomic Energy Commission by the

General Electric Company under Contract \# W-31-109-Eng-52

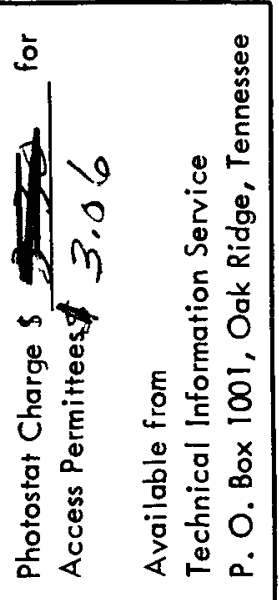

I'NCI. ASSIFEE 


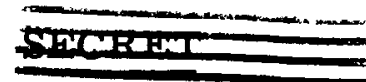

COPY NUMBER

1

2

3

4

5

6

7

8

9

10

11

12

13

14

15

16

17

18

19

20

21

22

23

$24-28$

29

30

31

32

33

\section{INTERNAL DISTRIBUTION}

A. B. Greninger - O. H. Greager

R. H. Beaton

W. K. Woods

R. B. Richards

W. I. Patnode

D. W. Pearce

G. W. Watt - University of Texas

W. K. MacCready

J. E. Maider

R. S. Bell

K. C. Vint - O. C. Schroeder

C. T. Groswith

J. M. Frame

C. A. Rohrmann

F. W. Albaugh

V. R. Cooper

F. W. Woodfield

R. E. Tomlinson

G. Sege

O. F. Hill - F. J. Leitz

C. M. Slansky

L. L. Burger

L. H. Clark

Extra Copies

700 File

300 File

$D$ and $C$ File

Pink Copy

Yellow Copy

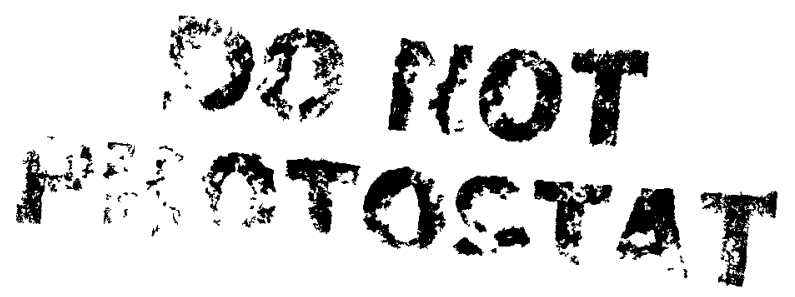

CONFIDENTIAL 


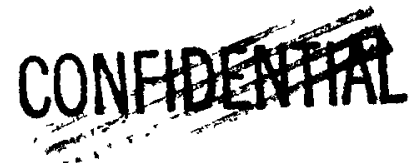

HW - 23141

Chemistry-Separation

Processes For Plutonium

And Uranium

COPY NUMBER
$34-40$
41
42
$43-49$
$50-52$
53
$54-55$
$56-63$
$64-65$
66
$67-72$
73
$74-77$
78
$79-82$
$83-85$
$86-88$
89
$90-93$
94
95
$96-99$
$100-101$
$102-116$

\section{EXTERNAL DISTRIBUTION}

\section{Argonne National Laboratory}

Armed Forces Special Weapons Project (Sandia)

Armed Forces Special Weapons Project (Washington)

Atomic Energy Commission, Washington

Brookhaven National Laboratory

Carbide and Carbon Chemicals Company (C-31 Plant)

Carbide and Carbon Chemicals Company (K-25 Plant)

Carbide and Carbon Chemicals Company (ORNL)

Carbide and Carbon Chemicals Company (Y-12 Area)

Chicago Patent Group

duPont Company

Hanford Operations Office

Idaho Operations Office

Iowa State College

Knolls Atomic Power Laboratory

Los Alamos

Mound Laboratory

Naval Research Laboratory

New York Operations Office

Patent Branch, Washington

Savannah River, Operations Office

University of California Radiation Laboratory

Vitro Corporation of America

Technical Information Service, Oak Ridge

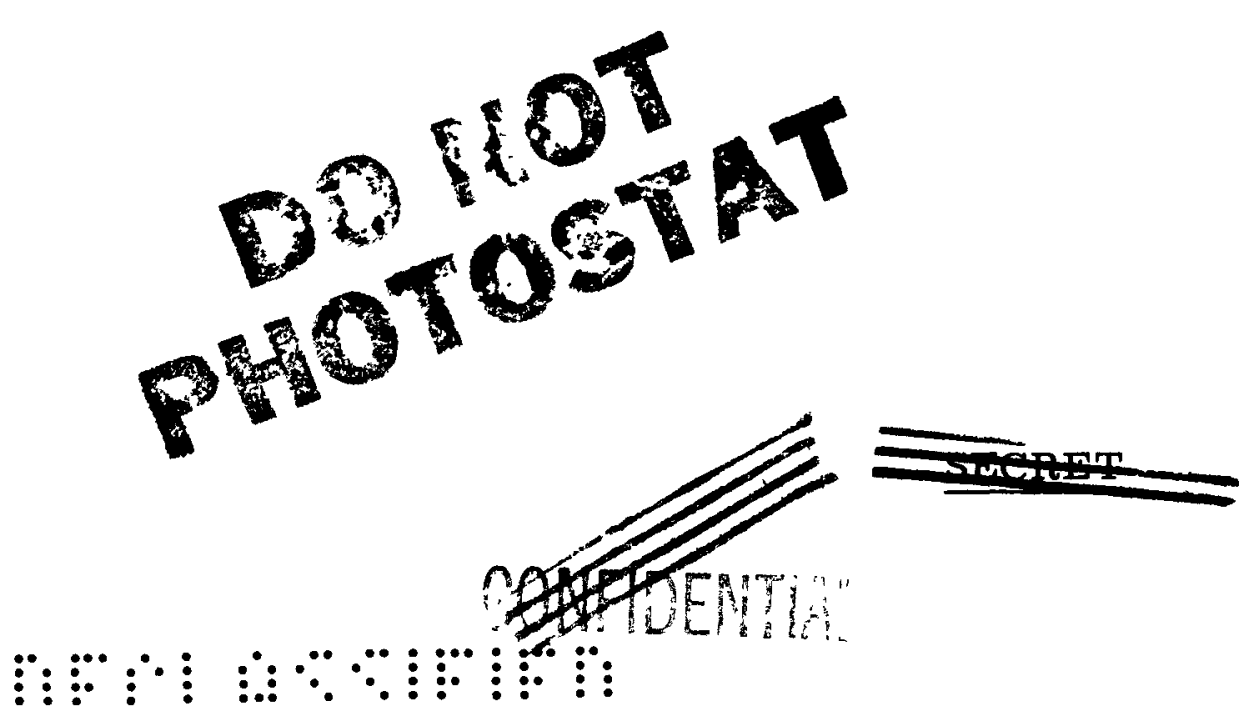




\section{CONEDEETTIALL \\ $-4-$}

HW - 23141

\section{THE VALVE-ACTUATED PULSE COLUMN}

DESIGN AND OPERATION

\section{INTRODUCTION}

The pulse column, originally described by Van Dijck ${ }^{(1)}$ for liquidliquid extraction combines many advantageous features that are present in batch contactors and in packed columns. Its virtue of having mechanical energy imparted to the extraction process in a countercurrent column was recognized by $C$. Groot who introduced the pulse column to the extraction problems of the atomic energy program $^{(2)}$ and demonstrated the greater efficiency of the pulse column over the conventional packed column. Application of the column to the Redox process was described by Burns, Groot and Slansky ${ }^{(3)}$ and subsequently the unit came into widespread use at AEC installations.

The many design and operational variables such as plate spacing, size and number of holes per plate, pulse size and frequency are largely interdependent, and when one adds to these the variations in the physical properties of the systems, he is confronted with design and operational problems that are largely subject to solution only trial and error.

Some effort has been expended in an attempt to obtain theoretical relations between some of these variables and various aspects of pulse column behavior such as drop size, rate of movement of drops, throughput and extraction efficiency during a given part of the cycle. ${ }^{(4)}$ These considerations were based on an idealized pulse column cycle consisting of four stages: (1) dispersion of phase I into phase II, (2) settling or disengaging of phase $I,(3)$ dispersion of phase I I into phase $I$, and (4) settling of phase II. Unfortunately, in ordinary pulse column operation these stages are not clearly defined due largely to the fact that only one phase is pulsed and to a certain amount of "back-up" in the connecting lines, $n$

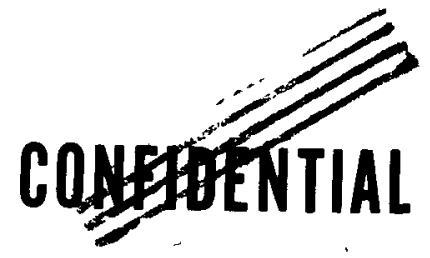


Further, the sine-wave nature of the conventional pulse cannot lead to a sharp separation of the above four stages.

A study of the fundamental extraction process was already underway at Hanford Works, and it was apparent that the idealized four stage cycle could be a convenient tool for further extraction studies particularly if the four stages could be made independent. At the same time such a study should provide information for more efficient design and operation of pulse columns.

A convenient method of meeting the above requirements is the control of each stream with solenoid valves. The flow or pulse size of a particular phase then becomes proportional to the product of the pressure ahead of the valve and the time interval that the valve is open. The second phase remains stationary during this interval. After a suitable independently timed delay, the second phase is then pulsed in the same manner.

The advantages of this scheme are a much greater degree of separation of the operating variables and the wide range of operating conditions. The purpose of this report is to present details of construction and operating data for a small research-type valve-actuated pulse column.

\section{SUMMARY}

A countercurrent extraction column is described which employs timed solenoid valves and pressurized feeds to provide a pulsing action to disperse the phases. The steps in the pulsing cycle are independent and thus provide greater separation of the operating variables than is possible with conventional pulse columns. The column described is particularly useful as a research tool for the study of extraction mechanism although a larger installation operating on the same principles should be quite workable. The 4-stage-cycle or mixer-settler type column operation has an 
inherent advantage in that the rapid coalescence and redispersion of phases are believed to lead to greater extraction than simple movement of a dispersed phase through a continous medium. In addition, the sharp pulse provided should produce greater turbulence than the more conventional pulsing arrangement. Some results of operation on the extraction and stripping of uranyl nitrate using tributyl phosphate as a solvent are included. These data correspond to Metal Recovery and Purex type systems.

\section{DESIGN AND CONSTRUCTION}

A complete schematic diagram is given in Figure 1 and details of the column construction are shown in Figure 2. Aside from the column itself, the essential components are the pumps which provide the feeds at the pressure tanks at the desired pressure, the valves which regulate the pulsed flow into and out of the column and the timer which controls independently the time of flow of each feed and the delay interval between the "feed pulses". The pumps used are positive displacement gear type having a displacement of $1.75 \mathrm{cc}$ per revolution (Zenith Products Company, size \# 3). They are driven by $1 / 15 \mathrm{Hp}$ constant-speed motors at an output shaft speed of about $150 \mathrm{r} . \mathrm{p} . \mathrm{m}$. The pressure tank is actually an air ballast of about 1 liter capacity and serves to provide a steady pressure, ahead of the pulse valves. The actual pressure is controlled by the bypass valve.

Solenoid valves (Skinner Electric $115 \mathrm{~V}, 60$ cycles) synchronized in pairs, control the flow or pulse into and out of the column. Available in several types, the ones employed here have a 3/32 inch orifice and are capable of operation up to 75 psig. The valves, as well as pumps and connecting lines, are stainless steel and gasketed where necessary with fluor othene.

The electrical circuit is shown by the dashed lines in Figure 1.

$$
5 / 19 \quad 004
$$


The heart of this system is the electronic timer which provides four timed circuits individually controlled by four dials on the instrument. Circuit 1 controls the on-time for valves 1 and 3 or the organic inlet and outlet valves, respectively. Circuit 2 provides a delay or dead time following the organic pulse during which there is no flow of liquid in the column. Circuit 3 governs valves 2 and 4 of the aqueous stream and circuit 4 controls the delay period following the aqueous pulse. Once the start switch is closed the cycle is repetitive, each circuit activating the following one. The time intervals of each of the four steps can be varied between 0.1 and 1.2 second. The timer calibrations are shown in Figure 3 and were obtained by using the 60 cycle supply voltage as a time standard. One lead from each timed circuit was attached through a $1000 \mathrm{ohm}$ resistance to a wire spring contact resting on a metal plate. The other lead from each circuit was connected to the plate. A strip of paper about 24 inches long was then painted with a solution of potassium iodide containing a little glycerine and placed between the contacts and the plate. With the timer dials.set at selected values the current was turned on while the paper was pulled at a constant rate under the contacts. A series of sharp brown dashes $1 / 120$ second in length appeared on the paper where free iodine was liberated and the number of dashes gave the time interval directly. These records remained legible for a period of several weeks. The complete schematic of the timer is given in Figure 4. One section of each 6SN7 contains a variable " $R-C$ " circuit. This timed circuit triggers the second section, dropping its plate current to zero which sends a positive pulse to the second 6SN7. Relays in the plate circuits of tubes 1 and 3 provide power to the solenoid valves.

In addition to the timer, external on-off and delay switches provide independent control over the outlet valves of each stream. The control switch indicated in Figure 1 permits the outlet valve to be continuously closed, continuously open, or connected directly to the timer. The delay switch is an auxiliary in the outlet valve circuit which permits the outlet

\section{$549 \quad 005$}


valve to open a short time after the inlet valve opens. This control aids in the interface control in the column. Figure 5 shows the diagram of the delay switch. With the constants shown the variable resistance $R$ provides a delay up to about 75 milliseconds.

The column itself is constructed of one inch diameter "True-Bore" tubing which is flared at each end to a two inch diameter. The end sections are shown in details in Figure 2. For the "four-stage" operating principle described above, double-faced or compound ${ }^{(5)}$ plates are very desirable, the organic-wetted side, fluorothene, being on the bottom for use with a solvent which is lighter than the aqueous phase. At the present time the column has 17 compound plates containing 0.026 inch diameter holes with $15 \%$ open area and separated by one inch spacers.

Provisions were made for operating this system at elevated temperatures by the installation of nichrome wire heaters on each inlet tube and a plexi-glass water jacket surrounding the column. The water jacket was constructed in a square design to permit motion pictures of the column in operation with minimum optical distortion. Thermocouples were placed at strategic points as indicated in Figure 1.

\section{OPERATION}

The flow rate of the feed or extractant into the column is dependent upon several factors. For a given size solenoid valve, the flow of each phase is proportional to the pressure in the ballast tank and the length of time the valve is open. By regulation of delay times, i.e., the time no liquid is flowing into the column, total flows may be increased or decreased without affecting the flow ratio. The frequency, or complete cycles per minute, is then determined by the sum of the durations of the four stages of the cycle and may be measured with a stop-watch or computed from the valve-open and delay times. 
With this column neither phase can be called continuous under the usual terminology, and successful operation of the column is dependent upon the maintenance of steady interfaces at both the top and bottom of the column. A shift of the interface position may be the result of (1) a volume change due to extraction, (2) entrainment of the dispersed phase, (3) air bubbles in the column, or (4) leakage through the closed valves or different operating characteristics of the valves. Factor (1) is inevitable and must be corrected for. Factor (2) generally occurs although the amount may be small. There is no direct evidence of factors (3) or (4) with the present equipment. Control of the interface is the most difficult operating problem and can be achieved to some extent by trial and error manipulation of on-off times and operating pressures. The use of the delay circuits in the outlet valve aids in building up the volume of that phase. A more direct control is provided by the bleeder valves at either end of the column. These are solenoid operated and when required are synchronized to open during the pulse from the opposite end of the column. Thus, while the organic phase is being removed at the top of the column, a small portion of the essentially unchanged aqueous feed can be bled out, through the combination needle valve-solenoid valve to lower the top interface. This feed, a very small fraction of the total, is recycled to the aqueous feed line.

The column has been tested on Metal Recovery and Purex systems involving $15 \%$ and $30 \%$ tributyl phosphate in a hydrocarbon type diluent.

Typical operation for two different plate geometries are represented by the data in Tables I and II. These plates were double-faced ffluorothene-stainless steel) and were drilled with either .039 inch or .026 inch diameter holes having an open area of $9 \%$ and $15.5 \%$, respectively. These two sets of plates are referred to as plate design $A$ and plate design $B$, respectively. With these plates separated at one inch or two inch intervals, successful operation has been achieved over the following range of

\section{$549 \quad 007$}


TABLE I

\section{TYPICAL OPERATING CONDITIONS OF THE VALVE-ACTUATED PULSE COLUMN}

ORGANIC PULSE

\begin{tabular}{|c|c|c|c|c|c|}
\hline \multicolumn{6}{|c|}{ ORGANIC PULSE } \\
\hline $\begin{array}{l}\text { Operating } \\
\text { Pressure } \\
\text { (psig) }\end{array}$ & $\begin{array}{l}\text { Pulse } \\
\text { Time } \\
\text { (sec) }\end{array}$ & $\begin{array}{c}\text { Pulse } \\
\text { Amplitude } \\
\text { (cm) }\end{array}$ & $\begin{array}{c}\text { Jet } \\
\text { Velocity } \\
\text { (cm/sec) }\end{array}$ & $\begin{array}{l}\text { Delay } \\
\text { Time } \\
\text { (Bec) }\end{array}$ & $\begin{array}{c}\text { Flow } \\
\text { (cc/min) }\end{array}$ \\
\hline
\end{tabular}

Plate Design B

\begin{tabular}{llllllr} 
V-PC-1g(IA) & 21 & 0.10 & 0.82 & 53 & 1.05 & 115 \\
V-PC-1P(IA) & 16 & 0.12 & 0.83 & 44 & 0.55 & 156 \\
VI-PC-1g(IC) & 50 & 0.13 & 0.58 & 28 & 0.71 & 100 \\
IX-PC-1h(IC) ** & 25 & 0.10 & 0.44 & 29 & 0.83 & 90 \\
& & & & & & \multicolumn{2}{c}{ Plate Design A } \\
II-PC-1L (IC) & 22 & 0.10 & 0.37 & 24 & 1.05 & 53 \\
I-PC-3a (RC) & 35 & 0.10 & 0.48 & 31 & 1.05 & 69
\end{tabular}

* See text, p. 9.

*2 inch plate spacing employed for this run. All others were 1 inch.
AQUEOUS PULSE

\begin{tabular}{|c|c|c|c|c|c|}
\hline $\begin{array}{c}\text { Operating } \\
\text { Pressure } \\
\text { (psig) }\end{array}$ & $\begin{array}{l}\text { Pulse } \\
\text { Time } \\
\text { (sec) }\end{array}$ & $\begin{array}{c}\text { Pulse } \\
\text { Amplitude } \\
\text { (cm) }\end{array}$ & $\begin{array}{c}\text { Jet } \\
\text { Velocity } \\
\text { (cm/sec) }\end{array}$ & $\begin{array}{l}\text { Delay } \\
\text { Time } \\
\text { (sec) }\end{array}$ & $\begin{array}{c}\text { Flow } \\
\text { (cc/min) }\end{array}$ \\
\hline
\end{tabular}

200.20

80.230 .46

$0.23 \quad 0.35$

$0.12 \quad 0.68$

15

0.82

0.71

0.79

0.45

65

52

37

138

0.18

0.54

0.43

19

0.82

0.82

76

$\begin{array}{llllll}15 & 0.14 & 0.43 & 20 & 0.82 & 62\end{array}$


OPERATING DATA FOR PULSE COLUMN

\begin{tabular}{|c|c|c|c|c|c|c|c|c|c|c|c|c|c|}
\hline \multirow[b]{2}{*}{ Run No. } & \multirow{2}{*}{$\begin{array}{c}\text { Flow Ratio } \\
\text { Aq/Org } \\
\end{array}$} & \multirow{2}{*}{$\begin{array}{l}\text { Flow (Total) } \\
\mathrm{gal} / \mathrm{ft}^{2} / \mathrm{hr}\end{array}$} & \multirow{2}{*}{$\begin{array}{c}\begin{array}{c}\text { Cycles } \\
\text { per } \\
\text { Min. }\end{array} \\
\end{array}$} & \multicolumn{2}{|c|}{$\begin{array}{c}\begin{array}{c}\text { Valve "On" Time } \\
\text { (sec) }\end{array} \\
\end{array}$} & \multicolumn{2}{|c|}{$\begin{array}{c}\begin{array}{c}\text { Valve "Off" Time } \\
(\mathrm{sec})\end{array} \\
\end{array}$} & \multicolumn{2}{|c|}{$\begin{array}{c}\text { Operating } \\
\text { Pressure } \\
\text { (psig) } \\
\end{array}$} & \multicolumn{2}{|c|}{ Mat. Bal. (\%) } & \multirow{2}{*}{$\begin{array}{c}\text { Waste } \\
\text { Conc. } \\
\text { UNH(g/1) } \\
\end{array}$} & \multirow{2}{*}{$\begin{array}{l}\text { HETS } \\
\text { (in) }\end{array}$} \\
\hline & & & & Organic & Aqueous & Org-Aq & Aq-Org & $\underline{\text { Org }}$ & $\underline{A q}$ & $\underline{\mathrm{UNH}}$ & $\underline{\mathrm{HNO}}_{3}$ & & \\
\hline \multicolumn{14}{|c|}{ Metal Recovery RC Data (Plate Design-A) } \\
\hline$I-P C-2 a$ & 0.78 & 410 & 28 & 0.10 & 0.15 & 1.05 & 0.82 & 28 & 15 & 107 & 110 & 20.7 & 32.1 \\
\hline$I-P C-2 b$ & 0.82 & 408 & 28 & 0.10 & 0.15 & 1.05 & 0.82 & 28 & 15 & 92 & 104 & 21.3 & 32.7 \\
\hline $\mathrm{I}-\mathrm{PC}-\mathbf{3 a}$ & 0.89 & 384 & 28 & 0.10 & 0.14 & 1.05 & 0.82 & 35 & 15 & 105 & 102 & 19.4 & 36.2 \\
\hline $1-P C-3 h$ & 0.92 & 610 & 28 & 0.15 & 0.16 & 1.05 & 0.80 & 33 & 23 & 98 & 84 & 19.2 & 39.5 \\
\hline I-PC-3f & 1.00 & 677 & 28 & 0.15 & 0.16 & 1.05 & 0.80 & 33 & 22 & 103 & 99 & 19.4 & 40.5 \\
\hline
\end{tabular}

II-PC- $1 \mathrm{~L} \quad 1.45 \quad 380$

\section{Purex IC Data (Plate Design-A)}

$\begin{array}{llllllrlrll}0.10 & 0.18 & 1.05 & 0.82 & 22 & 12 & 97 & 102 & 63.6 & 14.9 & 1 \\ 0.10 & 0.18 & 1.05 & 0.82 & 22 & 12 & 95 & 102 & 67.3 & 16.2 & 2 \\ 0.10 & 0.18 & 1.05 & 0.82 & 22 & 12 & 105 & 100 & 73.8 & 15.7 & 1 \\ 0.10 & 0.21 & 1.05 & 0.82 & 22 & 12 & 103 & 107 & 66.3 & 14.9 & \\ 0.10 & 0.21 & 1.05 & 0.82 & 23 & 12 & 96 & 95 & 61.5 & 16.0\end{array}$

Purex IC Data (Plate Design-B)

\begin{tabular}{|c|c|c|c|c|c|c|c|c|c|c|c|c|c|}
\hline VI-PC-1g & 1.18 & 640 & 34 & 0.13 & 0.12 & 0.71 & 0.79 & 50 & 52 & 101 & 110 & 59.5 & 8.5 \\
\hline VI-PC-1e & 1.47 & 457 & 28 & 0.10 & 0.12 & 1.06 & 0.82 & 43 & 45 & 102 & 104 & 42.2 & 8.5 \\
\hline VI-PC - Id & 1.49 & 468 & 30 & 0.10 & 0.12 & 1.06 & 0.71 & 42 & 45 & 103 & 116 & 39.0 & 8.3 \\
\hline VI-PC-1c & 1.58 & 528 & 39 & 0.10 & 0.12 & 0.62 & 0.71 & 40 & 42 & 99 & 109 & 29.0 & 8.1 \\
\hline VI-PC-1a & 1.66 & 415 & 30 & 0.10 & 0.12 & 0.92 & 0.82 & 40 & 40 & 107 & 120 & 39.4 & 8.5 \\
\hline
\end{tabular}

\section{Purex IA Data (Plate Design-B)}

$\begin{array}{lll}\text { V-PC-1g } & 1.77 & 530 \\ \text { V-PC-10 } & 1.95 & 530 \\ \text { V-PC-4b } & 2.03 & 560 \\ \text { V-PC-1b } & 2.14 & 618 \\ \text { V-PC-1p } & 2.37 & 654\end{array}$

$\begin{array}{rrrrrrrrrr}0.10 & 0.20 & 1.05 & 0.82 & 21 & 20 & 91 & 97 & 2.6 & 8.0 \\ 0.11 & 0.25 & 0.98 & 0.75 & 18 & 10 & 101 & 98 & 0.88 & 7.0 \\ 0.13 & 0.14 & 0.48 & 0.65 & 15 & 13 & 102 & 100 & 0.87 & 7.5 \\ 0.15 & 0.19 & 1.05 & 0.65 & 27 & 22 & 104 & 97 & 1.04 & 7.8 \\ 0.11 & 0.23 & 0.55 & 0.71 & 16 & 8 & 97 & 102 & 0.66 & 8.0\end{array}$

* See text, p. 9. 
operating" conditions:

$\begin{array}{ll}\text { Feed pressures } & 4-50 \mathrm{psig} \\ \text { Frequency } & 20-100 \mathrm{cycles} \text { per minute } \\ \text { Pulse amplitude } & 1 / 8-1 \mathrm{inch} \\ \text { Feed pulse time } & 0.07-0.3 \mathrm{sec} \\ \text { Jet velocity } & 10-50 \mathrm{~cm} \mathrm{sec}-1 \\ \text { Delay intervals } & 0.2-1.5 \mathrm{sec} \\ \text { Flow rate } & 400-1100 \mathrm{gal} \mathrm{ft}-2 \mathrm{hr}^{-1} \\ \text { Temperature } & 25^{\circ}-70^{\circ} \mathrm{C} \text {. }\end{array}$

In Table $I$ actual operating conditions of typical experiments are shown. Table I I lists actual operating data for typical room temperature runs. Metal Recovery runs were based on Flowsheet HW \# $4^{(6)}$ and Purex runs were based on Flowsheet ORNL \#2. ${ }^{(7)}$ No runs were made on the Metal Recovery "RA'" system.

Shell "Spray Base" was used as the diluent giving the organic phase a viscosity of about 18 millipoises and a density of $0.81 \mathrm{gms} / \mathrm{cc}$ at $25^{\circ} \mathrm{C}$. Although these data represent typical runs on the present equipment, they do not necessarily represent optimum extraction conditions. It is encouraging to note, however, that column efficiencies were in general quite good and for the Purex system HETS values of 7-8 inches were obtained for both extraction and stripping. Detailed consideration of changes in operating variables such as temperature, pulse size, pressure and flow rates, as well as design variables such as hole size and plate separation will be given in another report.

LLB:LHC:mb

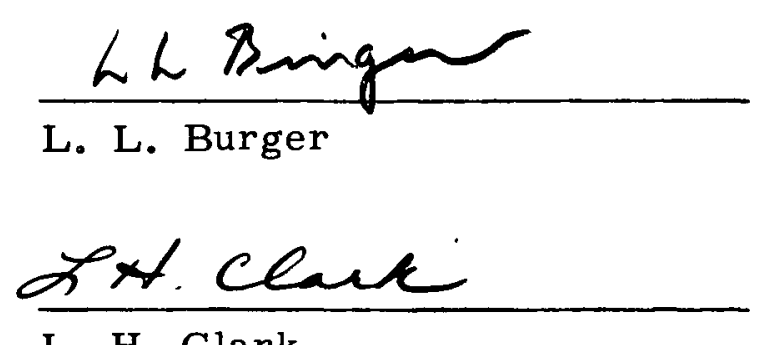

L. H. Clark 


\section{REFERENCES}

1. Van Dijck. U.S. Patent 2, 011, 186 (1935).

2. C. Groot. HW-11841, p. 29 (1948)。

3. W. A. Burns, C. Groot and C. M. Slansky. HW-14728 (1949).

4. L. L. Burger. HW-14743, p. 15 (1949).

5. W. A. Burns and W. F. Johnson. HW-19145, p. 6 (1950).

6. R. E. Smith. HW-18169 (1950).

7. F. R. Bruce and W. B. Lanham. CF-50-12-4 (1950). 


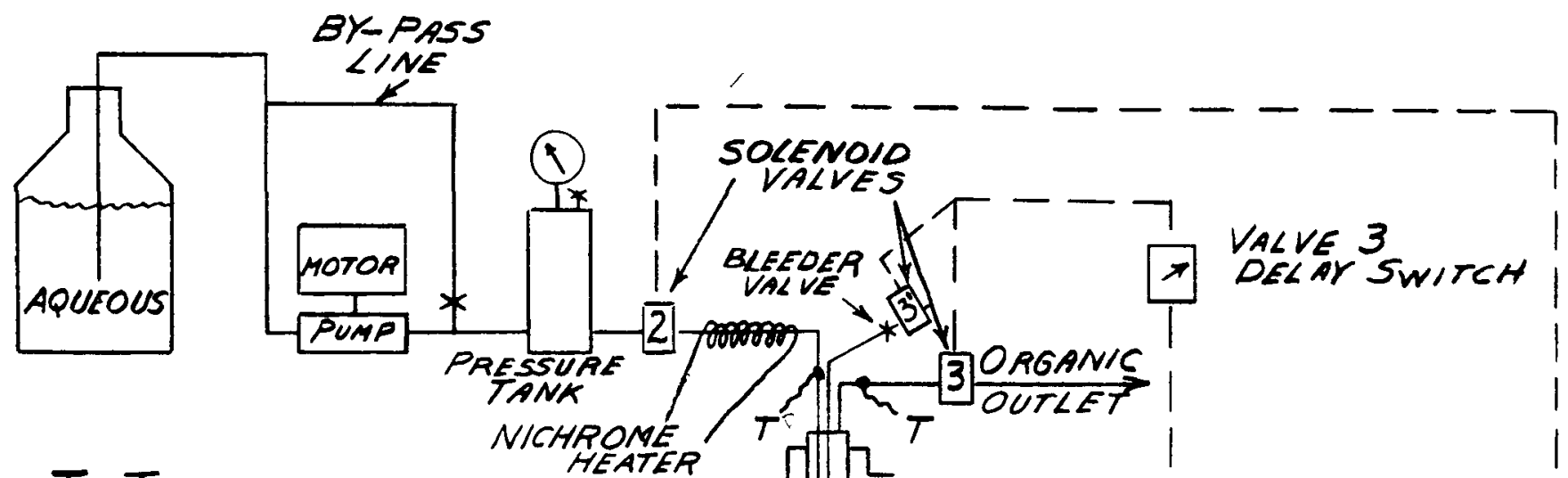

$T=$ THERMOCOUPE

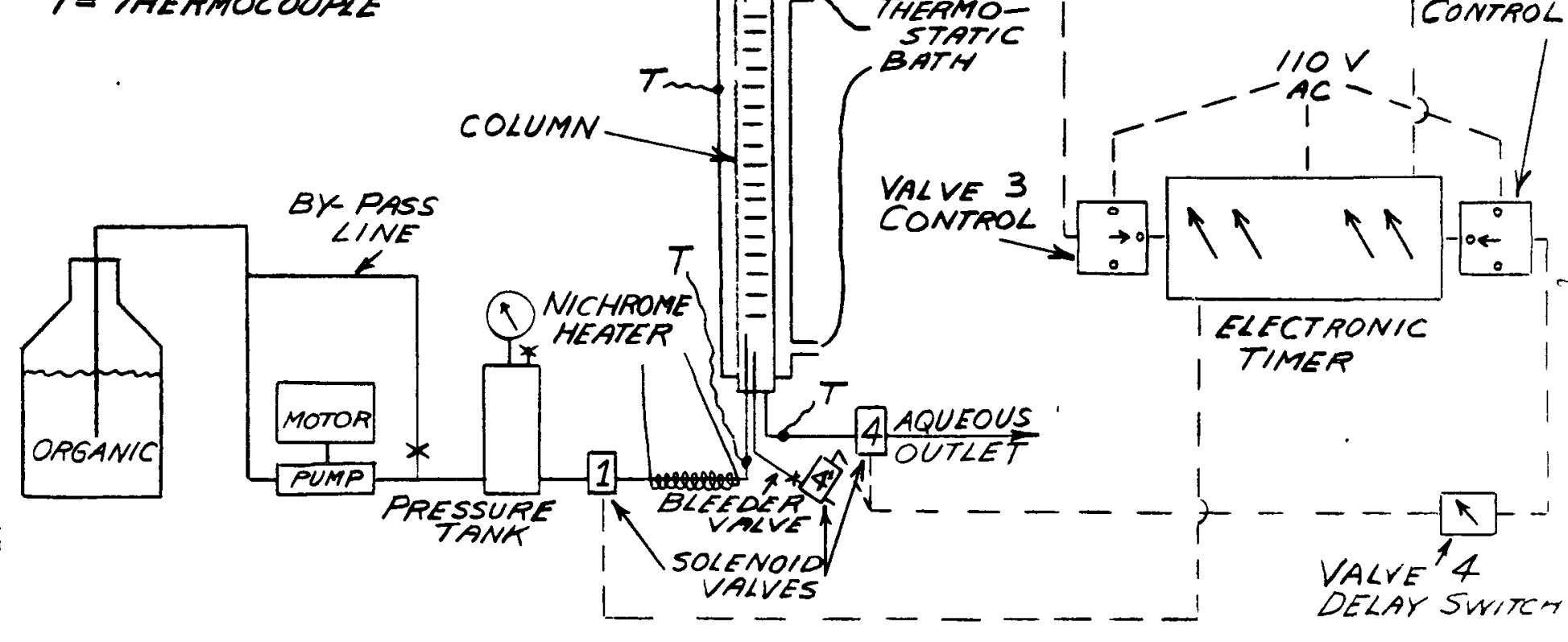

FIGURE 1 


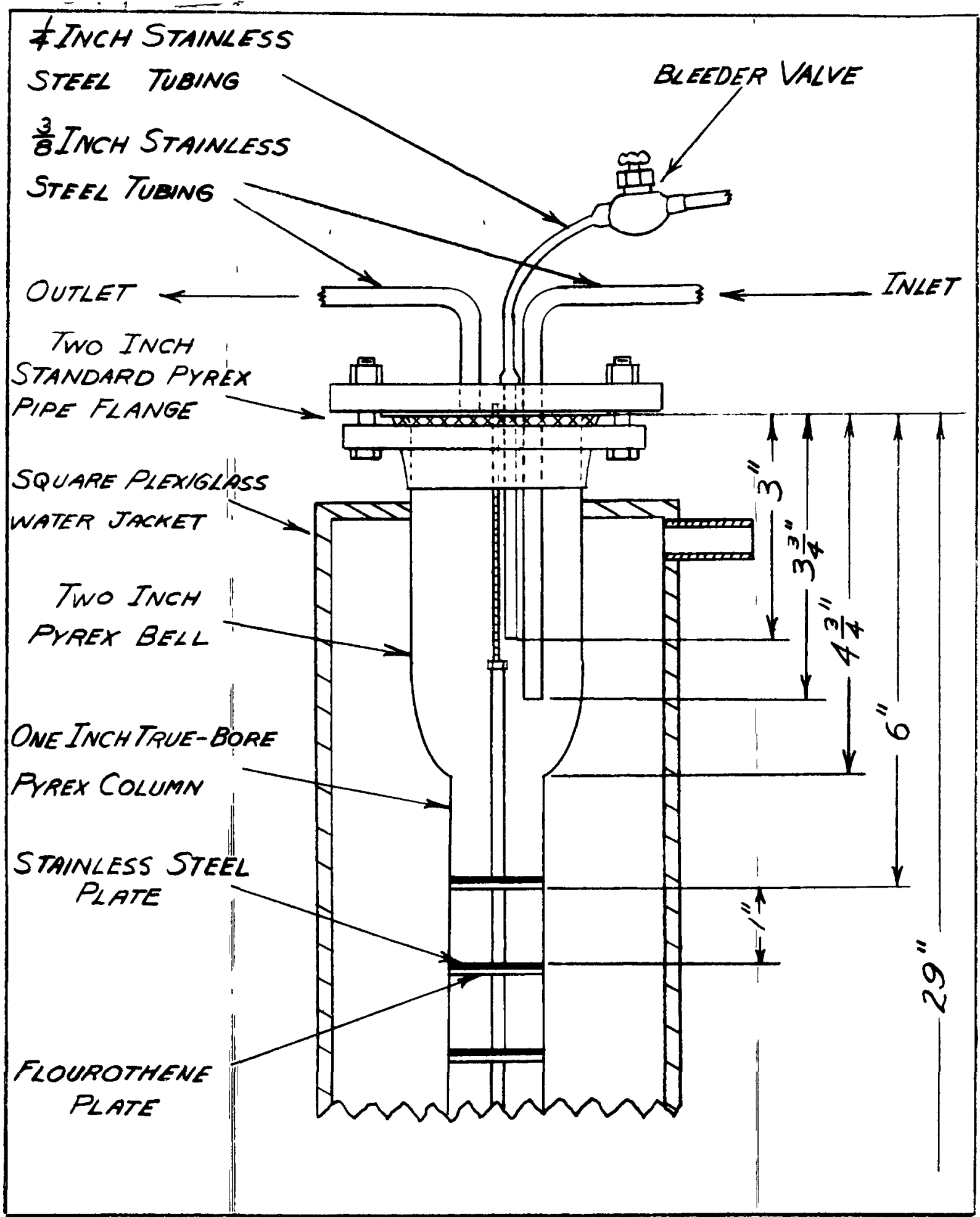

FIGURE 2

END SECTION OF PULSE COLUMN

$549 \cdot 013$ 
DIAL SETTING

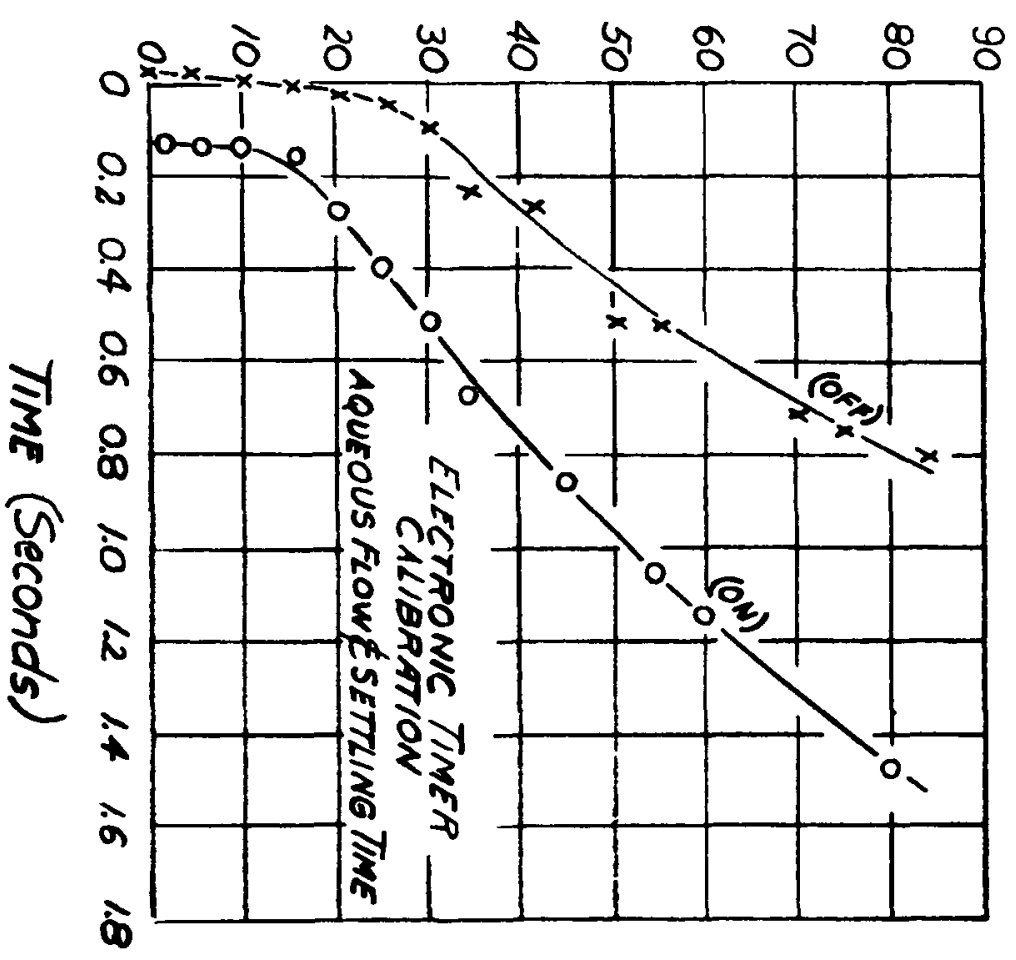

Dial Setting
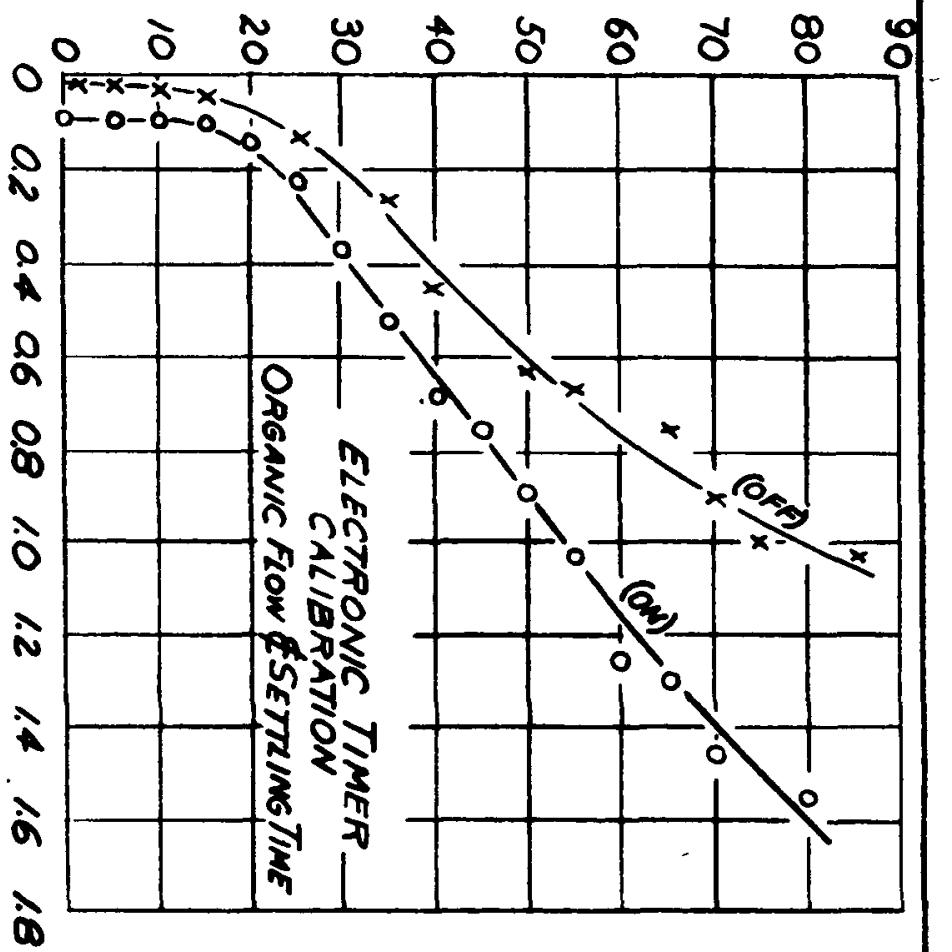


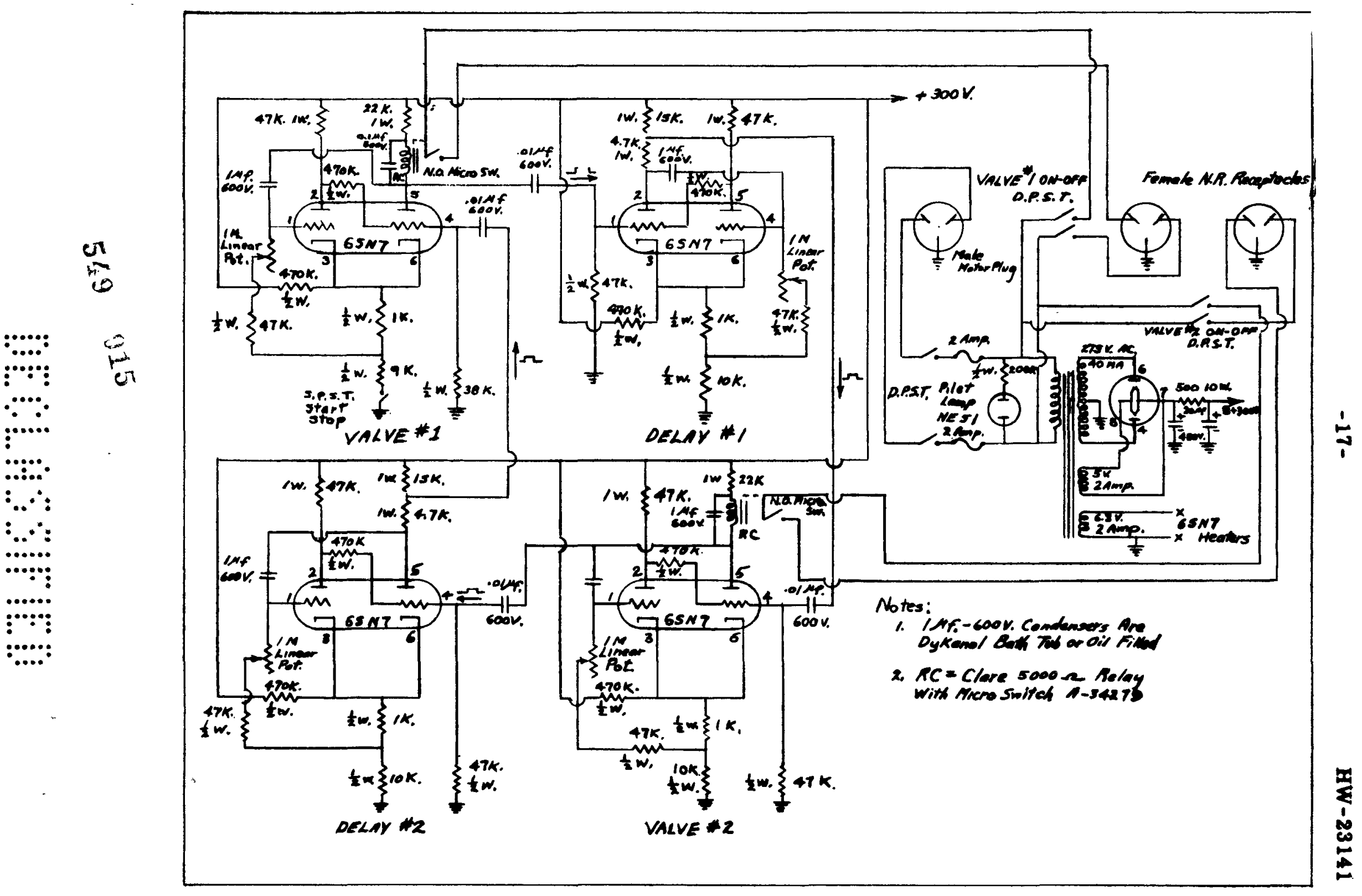

FIGURE 4

WIRING DIAGRAM OF ELECTRONIC TIMER 


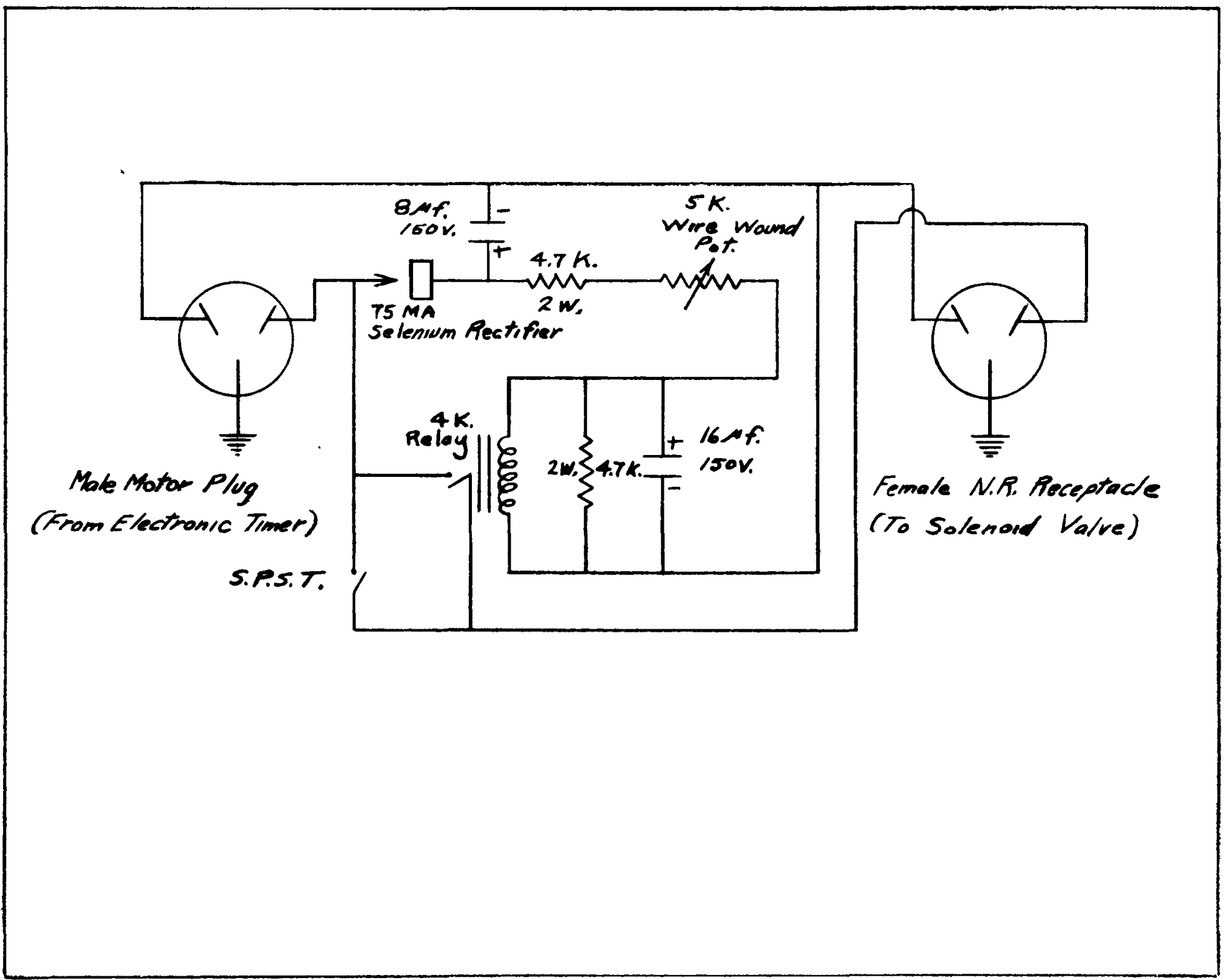

